\title{
Experience of Carpal Tunnel Syndrome that Operated Using a Limited Uni Skin Incision
}

\author{
Sinurlandurulmıs Tek Cilt Insizyonu ile Opere Edilen KarpalTünel \\ Sendromu Deneyimimiz
}

\author{
Hasan Serdar ISIK ${ }^{1}$, Ugur BOSTANCI ${ }^{2}$ \\ ${ }^{1}$ Ordu University, Medical Faculty, Department of Neurosurgery, Ordu, Turkey \\ ${ }^{2}$ Mehmet Aydin Education and Research Hospital, Department of Neurosurgery, Samsun, Turkey
}

Correspondence address: Hasan Serdar ISIK / E-mail: serdarisik1@hotmail.com

\begin{abstract}
AIM: Releasing the carpal tunnel for Carpal Tunnel Syndrome (CTS) is the most common surgical procedure in neurosurgical practice. In this study, we aimed to analyze the outcome of patients operated on for carpal tunnel syndrome using a limited uni skin incision.

MATERIAL and METHODS: Between June 2007 and November 2009, we performed 143 carpal tunnel releasing procedures for 126 patients. There were 112 (\% 89) female and 14 (\% 11) male patients with a mean age of $53(27-81) .79$ operations were performed for the right hand and 64 for the left hand.

RESULTS: Each patient was evaluated with their history, physical examination and electromyelography (EMG). All patients had brachialgia paraesthetica nocturna and severe CTS by EMG. Pre- and post-operative Visual Analog Scale (VAS) and Visual Analog Patient Satisfaction Scales (VAPSS) were used for clinical evaluation. There was no complication such as bleeding or nerve injury in the operated patients. The mean follow up period was 13 months (3-24 months). The mean VAS score was 7.9 pre-operatively and 2.8 post-operatively and the mean VAPSS score was 8.1. Three patients underwent re-operation because of the recurrence of symptoms. There was no procedure-related complication during the follow-up period.
\end{abstract}

CONCLUSION: The limited uni skin incision is a safe and effective minimal invasive procedure for releasing the carpal tunnel.

KEYWORDS: Carpal Tunnel Syndrome, Uni-skin incision, Minimally invasive

öz

AMAÇ: Nöroşirürji pratiği içinde, en sık uyguladığımız cerrahi işlem Karpal Tünel serbestleştirilmesidir.Bu çalışmada sınırlandırılmış cilt insizyonu kullanılarak opere edilen Karpal Tünel Sendrom'lu (KTS) hastalarımızı değerlendirmeyi amaçladık.

YÖNTEM ve GEREÇ: Haziran 2007 ile Kasım 2009 tarihleri arasında 126 hasta için 143 operasyon gerçekleştirildi. Hastaların 112'si (\% 89) kadın, 14 'ü (\% 11) erkekti. Ortalama yaş 53 (27-81) olarak bulundu. Operasyonların 79'u sağ el, 64'ü sol el için uygulandı.

BULGULAR: Hastalar öyküleri, fizik muayeneleri ve elektromiyografi (EMG) sonuçları ile değerlendirildiler. Opere edilen tüm hastalarda gece uykudan uyandıran ağrı (brachialgia paraesthetica nocturna) ve EMG'de ağır KTS bulguları olması şartı arandı. Klinik değerlendirme için, pre ve post operatif Görsel Analog Ağrı Skalası ve Görsel Analog Hasta Tatmini Skalası kullanıldı. Ortalama Görsel Analog Ağrı Skoru operasyon öncesi 7,9 iken operasyon sonrası 2,8 bulundu. Ortalama Görsel Analog Hasta Tatmini Skoru ise 8,1'di. 3 hasta, semptomlarının tekrarlaması üzerine tekrar opere edildiler. Hastaların takiplerinde operasyon tekniği ile ilgili herhangi bir komplikasyon ile karşılaşılmadı.

SONUÇ: Sınırlandırılmış tek cilt insizyonu Karpal Tünel Sendromu için güvenli ve etkili, minimal invaziv bir yöntemdir.

ANAHTAR SÖZCÜKLER: Karpal Tünel Sendromu, Tek cilt insizyonu, Minimal invaziv

\section{INTRODUCTION}

The carpal tunnel syndrome (CTS) is one of the most common peripheral neuropathies and is caused by the compression of the median nerve at the wrist region. It results in symptoms of dysesthesia and burning pain in the hand and it mainly affects the middle-aged female population $(1,2,10,22,25)$. CTS accounts for $90 \%$ of all entrapment neuropathies and its incidence is approximately $1 \%$ in the general population $(5,16,18,25)$. Palmer et al. reported in 1995 that between
400.000 and 500.000 cases require surgical treatment per year in the United States (21).

History, physical examination and electrophysiological results must be evaluated for the diagnosis of CTS $(5,6,7)$. Patients with mild symptoms of CTS can be managed with conservative treatment including non-steroid anti-inflammatory drugs, vitamin $\mathrm{B} 6$, local steroid injections or hand braces $(2,5,15)$. Surgical treatment is generally required in patients with moderate and severe symptoms (15). Various methods have 
been described for the surgical treatment of CTS. Standard open carpal tunnel release with a long palmar curvilinear incision still remains to be the preferred surgical procedure for many departments and neurosurgeons $(5,9,16)$, but this procedure has many complications including pillar pain, scar tenderness, cosmetic problems, loss of grip and pinch strength or time losses due to inability to work $(1,2,5,6,13,16)$. Endoscopic techniques and different limited skin incisions are described in the literature to minimize these complications $(3,4,6,8,11,12)$. The aim of this study was to analyze the results of patients who were operated by using microsurgical limited uni-skin incision.

\section{MATERIAL and METHODS}

This study was approved by the Local Ethical Committee (Samsun Mehmet Aydın Education and Research Hospital, Local Ethical Committee).All the patients and their families were informed about the operation technique before the operation.

Between June 2007 and November 2009, we performed 143 carpal tunnel releasing procedures on 126 consecutive patients. There were 112 (89\%) female and 14 (11\%) male patients with a mean age of 53 (ranging from 27 to 81). 79 operations were performed on the right hand and 64 were performed on the left. The mean follow-up period was 13 months (ranging from 3 to 24 months).

Each patient was evaluated with his/her history, physical examination and electromyelography (EMG). Brachialgia paraesthetica nocturna and numbness were observed in all patients. Additional symptoms and signs included positive Phalen's test in 119 hands ( $83 \%$ ) and positive Tinel's sign in 112 hands (78\%). The pain status of the patients was preand postoperatively assessed with the Visual Analog Scale (VAS). Incision scar hypersensitivity and cosmetic results were evaluated with the Visual Analog Patient Satisfaction Scale (VAPSS) postoperatively.

All operations were performed in the operating room under sterile conditions in the supine position. Before surgery, the affected hand, wrist and forearm were cleaned with povidone iodine solution (Isosol $1000 \mathrm{ml}$, Merkez Laboratory, Istanbul, Turkey). The area to be operated was covered with a sterile compress. Local anesthesia was performed with $2 \%$ prilocain hydrochloride (Citanest 20 ml, Flacon Astra Zeneca, Istanbul, Turkey) and no tourniquet was used. An operative microscope was utilized in all operations. The hand should be in a extended position and the surgeon's view from the operative microscope should be along the carpal tunnel. This position allows a good surgical route. After these routine operation preparations, a longitudinal $1 \mathrm{~cm}$ long incision was performed at the wrist region, proximal to the distal flexion crease, between the third and fourth finger (Figure 1). The incised skin was retracted with the help of a mini retractor and subcutaneous fat tissue was dissected laterally. The proximal part of the carpal ligament was passed with a surgical blade, and then the ligament was cut with scissors (Figure 2). After

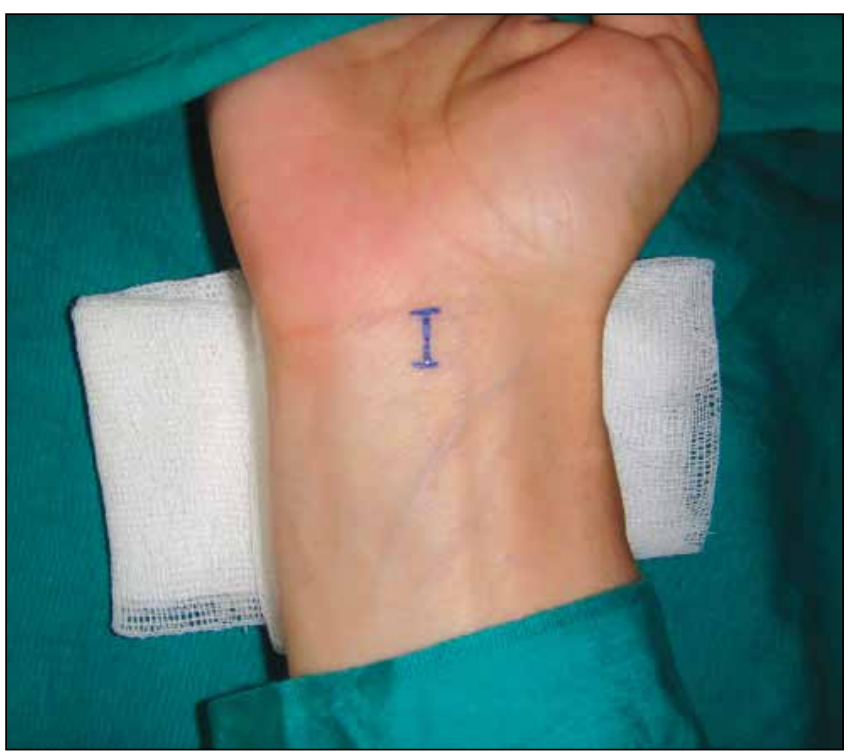

Figure 1: Preoperative marking of the surgical incision.

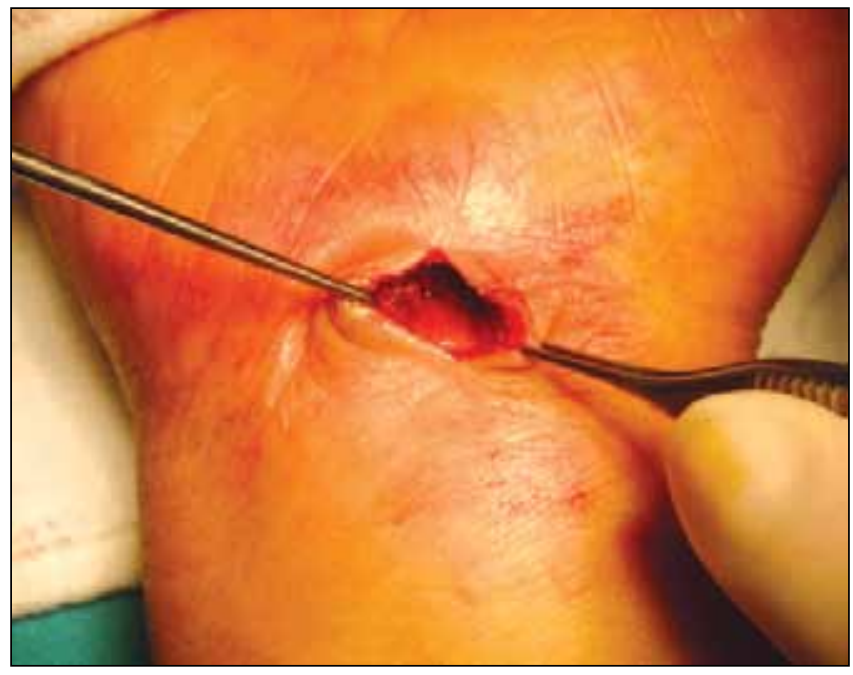

Figure 2: Peroperative appearance of $\mathrm{N}$. medianus after releasing the carpal tunnel.

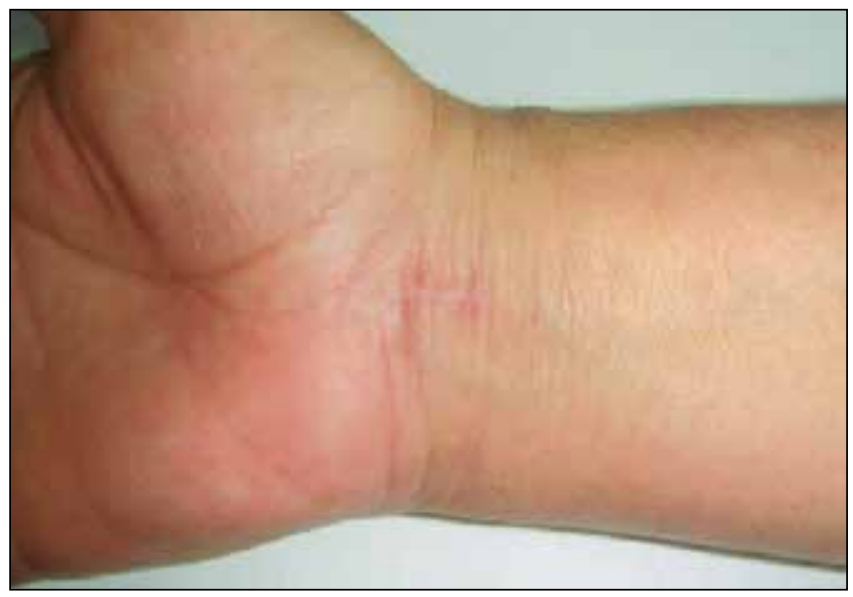

Figure 3: The skin incision (1 cm. length) appearance after an operation performed 4 months ago. 
the irrigation and homeostasis, the skin was sutured with 4/0 sutures subcutaneously and it was not required to remove the sutures (Figure 3). The mean operation time was 15 minutes (ranging between 10-20 minutes). The mean hospital stay was 5 hours (2-8 hours).

\section{RESULTS}

In this study, 143 carpal tunnel release operations were performed on 126 patients. There were no complications during the operations such as bleeding or nerve injury. The mean follow up period was 13 months and no procedurerelated complication was observed such as skin infection and palmar tenderness. The mean pre-operative VAS score for pain was 7.9, which decreased to 2.8 postoperatively. We used the Visual Analog Patient Satisfaction Scale described by Kılınçer and Zileli in 2006 (17) to evaluate the patients for cosmetic results, return to daily routine activities, palmar tenderness and scar sensitivity. Mean VAPSS score was 8.1 during the follow up period. In this study, 8 patients had temporary paraesthesia and 3 patients were reoperated because of pain recurrence and paraesthesia. Out of three patients, two were reoperated with the same technique, while in one patient we started a limited uni skin incision, which was later converted to a standard open incision because of the intensive scar tissue. No problem occurred during the follow-up period (mean 4 months).

\section{DISCUSSION}

CTS is a common condition causing burning hand pain, paresthesia and dysfunction. It affects mainly middle-aged female population $(1,2,5,7)$. In this study, just like in the literature, $89 \%$ of the patients were female with a mean age of $53(2,5,7)$.

In moderate and severe cases, surgery is the only treatment option that provides cure and there are many surgical techniques for releasing carpal tunnel. Until recent years, standard incision with a long curvilinear incision was the most performed technique by many neurosurgeons. This technique is safe and effective as reported by authors, but it has some complications $(2,5,9)$. Early complications including incomplete release of carpal ligament, injury to the palmar cutaneous and recurrent motor branch of median nerve or injury to the superficial palmar arch and ulnar artery are rare because the operation is performed under direct vision $(2,5)$. Late complications, on the other hand, have a relatively high incidence. These are hypertrophic scar formation, scar tenderness, pillar pain, loss of grip strength and sympathetic dystrophy resulting in the delay of returning to daily activities or work and emotional distress $(2,5,6,14)$. To reduce these complications, various limited incisions or endoscopic techniques are described by authors $(3,8,10,12,19,23,24,26)$. During the last two decades, endoscopic carpal tunnel release procedures have become popular and have been widely used by surgeons. In spite of the many advantages of endoscopic techniques, there are also some disadvantages. In 2008, Nazzi et al. drew attention to the disadvantages of endoscopic techniques; the difficulty of inserting a relatively large device through a narrow tunnel, nerve ischemia due to the use of tourniquet for a long time, performing transverse incision that might damage the superficial palmar arch and the experience needed for such an operation (20). Also it is reported that the most common complications of these techniques are paresthesia of the median and ulnar nerves, tendon lacerations and injury to the arteries $(2,5,7,13)$.

Some authors have also reported multiple limited mini open incision techniques to decrease the postoperative morbidity observed in standard open techniques $(6,8,11,16,22,23,25,26)$. Mini open procedures have been performed using either $a$ longitudinal incision on the wrist and/or palmar surface, or a transverse wrist incision. In 1996, Franzini et al. reported a minimally invasive technique with a small longitudinal incision of $1 \mathrm{~cm}$., proximal to the wrist crease. They performed 473 operations by using that incision and transillumination technique with $90 \%$ complete remission (14). In this study, we aimed to analyze the outcome of patients operated for carpal tunnel syndrome using microsurgical limited uni skin incision. This technique is the combination of Franzini's $1 \mathrm{~cm}$. longitudinal incision and the technique reported by Aydın et al. that allows the use of an operative microscope $(6,14)$. The incision is performed at the wrist region and the proximal part of distal flexion crease where the skin is thinner than the distal side and palmar surface; therefore, we thought that the complications including cosmetic problems, palmar tenderness and scar sensitivity would be less. In this study, we did not see any complication caused by the type of incision, and the mean VAPSS score was 8.1 when the patients were evaluated for cosmetic results, return to daily routine activities, palmar tenderness and scar sensitivity.

In 2008, Nazzi and Franzini reported a technical note about their experience of three different non-endoscopic minimally invasive surgical techniques for carpal tunnel release (20). They obtained $90 \%$ complete remission of symptoms with their first technique, which is the same as with our incision type. In our study, there were 3 reoperations because of the recurrence of symptoms and 8 patients had temporary paresthesia. 132 patients (92\%) had complete remission of pain and acceptable remission of numbness during the follow-up period.

In the literature, it is reported that either the recurrent thenar branch or palmar arteries have a potential risk of injury during all endoscopic and limited incision techniques (2). The recurrent thenar branch may leave the median nerve from various anatomic places. These variations may cause difficulties for the surgeon to release or protect the recurrent thenar branch. The palmar arteries, and particularly the superficial palmar arch, also have a potential risk due to the difficulties in visualization with these limited incisions or endoscopic techniques. However, just like the studies of Franzini and Aydın et al., we also did not experience any artery, nerve or tendon injury $(6,7,20)$. 


\section{CONCLUSION}

The microsurgical limited uni-skin incision technique for carpal tunnel release is a safe and effective surgical procedure. It can be used in the surgical treatment of CTS to achieve better palmar appearance, excellent cosmetic results and to reduce the complications of other standard techniques.

\section{REFERENCES}

1. Abdullah AF, Wolber PH, Ditto EW: Sequela of Carpal Tunnel surgery: Rationale for design of a surgical approach. Neurosurgery 37: 931-936, 1995

2. Açıkgöz B: Karpal Tünel Sendromu. TND Spinal ve Periferik Sinir Cerrahisi Grubu Yayınları: Periferik Sinir Cerrahisi Demircan N, Zileli M (ed). Ankara: Türk Nöroşirürji Derneği, 2008, 281-304

3. Agee JM, Mc Caroll HR, North ER: Endoscopic Carpal Tunnel release using the single proximal incision technique. Hand Clin 10: 647-659, 1994

4. Agee JM, Peimer CA, Pyret CD, et al: Endoscopic Carpal Tunnel release: $A$ prospective study of complications and surgical experience. J Hand Surg Am 20:165-171, 1995

5. Aroori S, Spence RAJ: Carpal Tunnel Syndrome. Ulster Med J 77: 6-17, 2008

6. Aydın K, Cokluk C, Cengiz N, Bilgici A: Microsurgical open mini uniskin incision technique in the surgical treatment of Carpal Tunnel Syndrome. Neurology India 54: 64-67, 2006

7. Aydın K, Cokluk C, Piskin A, Kocabıçak E: Ultrasonographically checking the sectioning of the transverse carpal ligament during Carpal Tunnel Surgery with limited uni skin incisions. Turkish Neurosurgery 17:219-223, 2007

8. Avci S, Sayli U: Carpal Tunnel release using a short palmar incision and a new knife. J Hand Surg Br 25:357-360, 2000

9. Badger SA, O'Donnel ME, Sherigor JM, Conolly P, Spence RA: Open Carpal Tunnel release, still safe and effective operation. Ulster Med J 77:22-24, 2008

10. Brown RA, Helbernan RH, Seiler JG, Abrahamsson SO, Weiland AJ, Urbaniak JR, Schoenfeld DA, Furcolo D: Carpal Tunnel release: a prospective randomized assessment of open and endoscopic methods. J Bone Joint Surg 75:1265, 1993

11. Cellocco P, Rossi C, Bizzarri F, et al: Mini-open blind procedure versus limited open technique for Carpal Tunnel release: $A$ 30-month follow-up study. Journal Hand Surgery 30:493-499, 2005

12. Chow JC: Endoscopic release of the carpal ligament: $A$ new technique for Carpal Tunnel Syndrome. Arthroscopy. 5:19-24, 1989
13. Einhorn N, Leddy JP: Pitfalls of endoscopic carpal tunnel release. Orthop Clin North Am 27:373, 1996

14. Franzini A, Broggi G, Servello D, Dones I, Pluchino MG: Transillumination in minimally invasive surgery for Carpal Tunnel release. Technical note. J Neurosurg 85:1184-1186, 1996

15. Huisstede BM, Randsdorp MS, Coert JH, et al: Carpal Tunnel Syndrome. Part 2. Effectiveness of surgical treatments. A systematic review. Arch Phys Med Rehabil 91:1005-1024, 2010

16. Lida J, Hirabayashi H, Nakase H, Sakaki T: Carpal Tunnel Syndrome: Electrophysiological grading and surgical results by minimum incision open carpal tunnel release. Neurol Med Chir (Tokyo) 48:554-559, 2008

17. Kılıcer C, Zileli: Visual analog patient satisfaction scale. Trakya Ü. Tıp Fak Derg 23:113-118, 2006

18. Mondelli M, Giannini F, Giacchi M: Carpal Tunnel Syndrome incidence in a general population. Neurology 58:289-294, 2002

19. Okada M, Tsubata O, Yasumoto S, et al: Clinical study of surgical treatment of Carpal Tunnel Syndrome: Open versus endoscopic technique. Journal of Orthopaedic Surgery 8:19-25, 2000

20. Nazzi V, Franzini A, Messina G, Broggi G: Carpal Tunnel Syndrome: Matching minimally invasive surgical techniques, Technical note. J Neurosurg 108:1033-1036, 2008

21. Palmer DH, Hanrahan LP: Social and economic costs of Carpal Tunnel surgery. Instr Course Lect 44:167-172, 1995

22. Sever C, Kulahci Y, Oksuz S, et al: The mini incision technique for Carpal Tunnel decompression using nasal instruments. Turkish Neurosurg 20:353-357, 2010

23. Teh KK, Ng ES, Choon SK: Mini Open Carpal Tunnel release using knifelight: Evaluation of the safety and effectiveness of using a single wrist incision (cadaveric study). J Hand Surg Eur 34E: 506-510, 2009

24. Trumble TE, Diao E, Abrams RA, et al: Single-portal endoscopic Carpal Tunnel release compared with open release: A prospective randomized trial. J Bone Joint Surg Am. 84:1107-1115, 2002

25. Uygur F, Sever C, Yüksel F: Comparing the results of limited incision technique and standart longitudinal incision technique for carpal tunnel decompression by numerical grading system. Turkish Neurosurgery 19:51-57, 2009

26. Wongsiri S, Suwanno P, Tangtrakulwanich B, et al: A new tool for mini Open Carpal Tunnel release - The PSU retractor. BMC Musculoskeletal Disorders 9: 126, 2008 